\title{
FIRST RECORD OF EIGHTBAR GROUPER, Epinephelus octofasciatus GRIFFIN, 1926 (PERCIFORMES: SERRANIDAE) FROM INDONESIA
}

\author{
Teguh Peristiwady \\ Technical Implementation Unit for Marine Biota Conservation, Indonesian Institute of Sciences, Bitung \\ Received September 16-2008; Received in revised form October 28-2008; Accepted November 7-2008
}

\begin{abstract}
Three specimens were collected by market collection at Winenet and Girian Market, Bitung, North Sulawesi, Indonesia on January until March 2008. Distribution of Epinephelus octofasciatus Griffin, 1926 is found as Australia, Chagos Islands, China Main, Comoros, France Polynesia, Guam, India, Japan, Kenya, Kermadec Islands, Korea Republic, Madagascar, Maldives, Marquesas Islands, Mauritius, North Marianas, New Caledonia, New Zealand, Norfolk island, Ogasawara Islands, Reunion, Ryukyu Islands, Singapore, Somalia, and South Africa. Its morphological features and diagnostic characters are discussed and illustrated
\end{abstract}

KEYWORDS: Epinephelus octofasciatus, Serranidae, Eightbar grouper, new record

\section{INTRODUCTION}

Lembeh Island is situated in the northern part of Sulawesi Island and bounded by open sea and Lembeh strait. Together with other country, such as, Philippines, Papua New Guinea, they located in the central of Indo-Pacific Ocean which it has an extremely rich and varied of fish fauna. This island is characterized by various ecosystems that are suitable for the development of the fishing activities such as coral reefs, mangroves, and seagrass beds. Although the fishing activity is become to modern fishing industry, fishing activity in this area still dominated by small scale fisheries mainly concehtrates on coastal areas. The most widely used gear is traditional net, such as light fishing, bamboo trap, seine net, gill net, etc. The commercial fishing activities were observed in this area mainly concentrates on the bottom living crustaceans and fish, such as, shrimp, lutjanids, groupers, etc.

The grouper is one of the largest important families on corals reefs. It may be found in marine, brackish, and freshwater environments but is primarily marine fish. The biggest number of species himself found and distributed in the tropical seas. Ecologically, grouper is playing an important role in the coral reef ecosystem as top predators. These fishes are also an important fishery resource throughout the tropics (Ralston, 1987; Heemstra \& Randall, 1993; Polunin \& Roberts, 1996) and are a favored target species of fishermen (Randall, 1987; Russ \& Alcala, 1996).

The family Serranidae belongs to the Class Actinopterygii (ray finned fishes) and the Order Perciformes. Nelson (1984) divided this family approximately to 35 genera and about 370 species with the dominant genus are Aiphestes, Anthias, Caesioperca, Centropristis, Cephalopholis, Dermatolepis, Diplectrum, Epinephelus, Gemoplectrus, Hemanthias, Hypoplectrus, Lioproma, Mycteroperca, Ocyanthias, Paralabrax, Paranthias, Pibea, Plectranthias, Promicrops, Pteranthias, Schultzea, and Serranus.

On about 10 years, Randall \& Heemstra (1991) revised this family to 62 genera and there are approximately 500 species with the big and varied in size range. This family is divided into three subfamilies, the Serraninae (sea basses), the Anthiirlae (fairy basslets and perchlets), and the Epinephelinae, with the latter arranged into five tribes. These are the Niphonini (Japanese ara or grouper), Epinephelini (groupers and coral trouts), Liopropomini (Swissguard basslets), and the Diploprionini and Grammistini (soapfishes).

Herein, the purpose of the present study is to inventory a new finding on fish species found from the Indonesian waters. It is hope that this finding will be used as a new baseline of the fisheries sciences which can stimulate future research in North Sulawesi and eastern Indonesian in general.

\section{MATERIALS AND METHODS}

Three specimens were collected by market collection at Bitung, North Sulawesi, on January until March 2008. The specimen collected from Winenet market, was caught by hook at a depth about $50 \mathrm{~m}$ at Dua Island, Lembeh Island; meanwhile the specimens collected from Girian market were caught by hook at a depth more than $75 \mathrm{~m}$ arround the coral reefs of Lirang, Lembeh Island, North Sulawesi. 
After collection, the specimens were immediately photographed, labeled with LBRCF (Reference Collection of Indonesian Institute of Sciences BitungFish) and preserved in formalin solution $10 \%$ and deposit at Technical Implementation Unit for Marine Biota Conservation, Indonesian Institute of Sciences, Bitung for further study. Valid record of the fish specimen was used data from Fishbase (Froese \& Pauly (ed.) 2006; Eschmeyer (ed.) 1998

Cyanin blue was used to examine and count scales. Measurements were made on the left side of specimen by using dial-point caliper to the nearest of $0.05 \mathrm{~mm}$. Length is recorded to $0.05 \mathrm{~mm}$ only for sizes under $150 \mathrm{~mm}$, length bigger than $150 \mathrm{~mm}$ is recorded to tenths of $\mathrm{mm}$. Total length is measured from the tip of snout to the tip of caudal fin. Standard length is taken from the front of the upper lip to the base of the caudal fin (end of hypural plate). Head length is measured from the front of the upper lip in the median plane to the end of the opercular membrane. Snout length is taken from the same anterior point to the fleshy edge of the orbit. Body depth is the greatest depth from the base of the dorsal fin, adjusting for any obvious malformations of preservation. Body width is the maximum width just behind the gill opening (anterior to the base of the pectoral fins). Orbit diameter is the greatest diameter to the fleshy edges of the orbit. Interorbital width is measured between eyes on top of head area. The length of the upper jaw is measured from the front of the upper lip to the posterior fleshy edge of the jaw. The depth of the caudal peduncle is the least depth, and the length of the caudal peduncle is taken horizontally from the rear base of the anal fin to the base of the caudal fin. Lengths of the dorsal and anal spines and rays are measured from the point they depart from the contour of the body. Dorsal fin base is taken from the anterior base of first dorsal rays to the end of the dorsal fin rays. Pectoral and pelvic fin lengths are the lengths of the longest ray. Anal fin base is taken from the base of anterior anal fin rays to the base of the end of anal fin rays.

\section{RESULTS AND DISCUSSION}

\section{Specimen Examined}

Observations and measurements based on 3 specimens: LBRCF-302, 182.00 mm SL, 18 January 2008, Dua Island, Lembeh, North Sulawesi; LBRCF$330,276,50 \mathrm{~mm}$ SL, 4 Maret 2008, Lirang, Lembeh, North Sulawesi; LBRCF-331, $332.00 \mathrm{~mm} \mathrm{SL}$; and 5 Maret 2008, Lirang, Lembeh, North Sulawesi.
Due to its preference for relatively deep water and because of their occurrence over or inside hard substrat, they can not apt to be taken by fishermen using trawls or gill net. Some authors mentioned Epinephelus octofasciatus Griffin 1926 (Figure 1) in their paper were Randall \& Heemstra (1991); Heemstra \& Randall (1993); Heemstra in Smith \& Heemstra (1995); Kuiter (1993); Francis (1993); Carpenter et al. (1997); Adam et al. (1998); Heemstra \& Randall, 1999 in Carpenter \& Niem (1999); Nakabo (2000); Randall in Randall \& Lim (2000); Randall \& Earle (2000); Hutchins (2001); Nakabo (2002); Manilo \& Bogorodsky (2003); Myers \& Donaldson (2003); Randall et al. (2004); Hoese et al. (2006).

\section{Diagnostic Characters}

Counts and measurements of three specimens Epinephelus octofasciatus Griffin, 1926 are given in Table 1. Dorsal fin continuous with 11 spine and 13 to 14 soft rays between spinous and soft portions not deeply notched; Anal fin with 3 spines and 7 to 8 soft rays 7 to 8 ; Pectoral fin with 17 rays; Ventral fin with 1 spine and 4 fin rays 4 .

Body depth 2.00 times in standard length. Rounded head with big lips. Snout short and blunt. Mouth large and oblique, the maxilla nearly reaching a vertical at posterior edge of eye; upper margin of preopercle finely serrate. Dorsal spines strong; their membranes deeply incised. Forth dorsal spine longest, lonser than the others; third and fifth spines almost equal. Third anal spine longer than the others; first anal ray less than head length. Pelvic fin rounded. Caudal rounded.

\section{Colour}

Color of fresh specimens head and body almost uniformly dark brown; juveniles and young adults with eight pale bars; first bar started from in front of dorsal fin to upper opercle behind eyes, six bars under dorsal fin and the last bar in the base of caudal fin. Tip of pectoral fin yellowish; tip of pelvic and anal soft rays blackish. Caudal peduncle black with white bar outside.

Adult fish with 5 dark bars below dorsal fin, the last 2 bars as broad as preceding bars, 2 pale interspaces below soft dorsal fin. Large adults are uniformly grey brown with a dark tail saddle blotch.

Occurs through out the Indo-West Pacific from South Africa to Japan, Australia, and New Zealand (Randall, 1999 in Carpenter \& Niem, 1999) (Figure 2). 


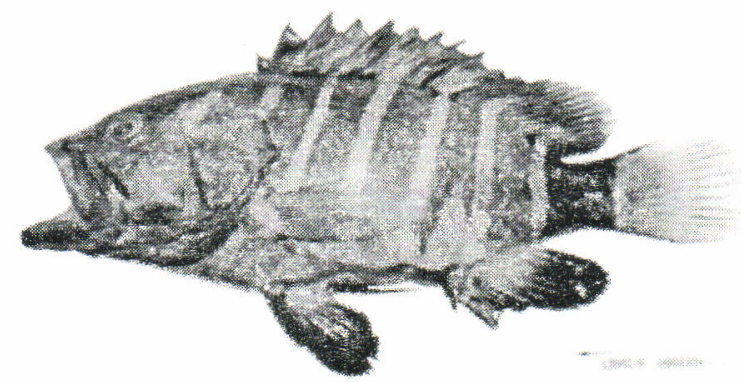

Figure 1. Epinephelus octofasciatus Griffin, 1926; CRDOA 6364, $182.00 \mathrm{~mm}$ SL from Bitung, North Sulawesi, Indonesia.

Table 1. Counts and measurements of Epinephelus octofasciatus Griffin, 1926

\begin{tabular}{|c|c|c|c|c|}
\hline \multicolumn{2}{|c|}{ Counts and measurements } & \multirow{2}{*}{$\begin{array}{l}\text { LBRCF-330 } \\
\mathrm{XI}, 13\end{array}$} & \multirow{2}{*}{$\frac{\text { LBRCF-331 }}{\mathrm{XI}, 14}$} & \multirow{2}{*}{$\frac{\text { LBRCF-302 }}{\mathrm{XI}, 14}$} \\
\hline Counts & Dorsal fin rays & & & \\
\hline & Anal fin rays & III, 7 & III, 8 & III, 8 \\
\hline & Pectoral fin rays & 17 & 17 & 17 \\
\hline & Ventral fin rays & 1,4 & I, 4 & I, 4 \\
\hline & Caudal fin rays & 17 & 16 & 17 \\
\hline \multirow[t]{34}{*}{ Measurements } & Body and head & & & \\
\hline & Total length & 351.50 & 416.00 & 228.00 \\
\hline & Standard length & 276.50 & 332.00 & 182.00 \\
\hline & Body depth & 109.90 & 139.45 & 72.70 \\
\hline & Body width & 56.60 & 73.45 & 33.80 \\
\hline & Head length & 115.95 & 142.25 & 80.05 \\
\hline & Snout length & 31.85 & 123.05 & 22.40 \\
\hline & Orbit diameter & 18.80 & 17.60 & 7.70 \\
\hline & Upper jaw length & 53.50 & 66.95 & 38.90 \\
\hline & Predorsal length & 103.80 & 121.15 & 71.95 \\
\hline & Preanal length & 196.00 & 253.00 & 135.20 \\
\hline & Prepelvic length & 112.45 & 144.85 & 80.10 \\
\hline & Caudal peduncle depth & 34.10 & 43.20 & 22.20 \\
\hline & Caudal peduncle length & 43.90 & 48.25 & 32.85 \\
\hline & Dorsal fin & & & \\
\hline & Dorsal fin base & 154.00 & 186.00 & 99.65 \\
\hline & First dorsal spine & 11.65 & 15.25 & 9.05 \\
\hline & Second dorsal spine & 31.90 & 39.05 & 21.90 \\
\hline & Third dorsal spine & 41.45 & 45.05 & 27.55 \\
\hline & Fourth dorsal spine & 42.15 & 46.05 & 28.20 \\
\hline & Fifth dorsal spine & 41.80 & 44.95 & 27.50 \\
\hline & Longest dorsal ray & 48.10 & 58.70 & 34.90 \\
\hline & Anal fin & & & \\
\hline & Anal fin base & 50.10 & 63.40 & 33.30 \\
\hline & First anal spine & 14.90 & 15.05 & 11.05 \\
\hline & Second anal spine & 27.90 & 19.70 & 20.30 \\
\hline & Third anal spine & 35.65 & 36.20 & 30.05 \\
\hline & Longest anal ray & 51.60 & 54.15 & 39.15 \\
\hline & Caudal fin & & & \\
\hline & $\begin{array}{l}\text { Caudal fin length } \\
\text { Pectoral fin }\end{array}$ & 58.75 & 67.15 & 38.05 \\
\hline & $\begin{array}{l}\text { Pectoral fin } \\
\text { Pectoral fin length }\end{array}$ & & 76.35 & 44.80 \\
\hline & $\begin{array}{l}\text { Pectoral fin length } \\
\text { Pelvic fin }\end{array}$ & 65.70 & & \\
\hline & Pelvic spine length & 35.15 & 41.05 & 24.90 \\
\hline & Pelvic fin length & 61.90 & 63.20 & 42.20 \\
\hline
\end{tabular}


Froese \& Pauly (2006) noted the countries where Epinephelus octofasciatus is found as Australia, Chagos Islands, China Main, Comoros, France Polynesia, Guam, India, Kenya, Kermadec Is. Korea Republic, Madagascar, Maldives, Marquesas Is., Mauritius, North Marianas, New Caledonia, New Zealand, Norfolk Island, Ogasawara is., Reunion, Ryukyu Is., Singapore, Somalia, and South Africa as show Figure 3.
There are numerous technical or research reports published earlier, which contain information on fishes of the Indonesian waters. However, most of these report concentrate on community structure of some coastal ecosystems and realized by sensus visual method. In the world, valid record for Epinephelus octofasciatus Griffin (1926) were reported from Chagos Is. (Winterbottom \& Anderson, 1997); France

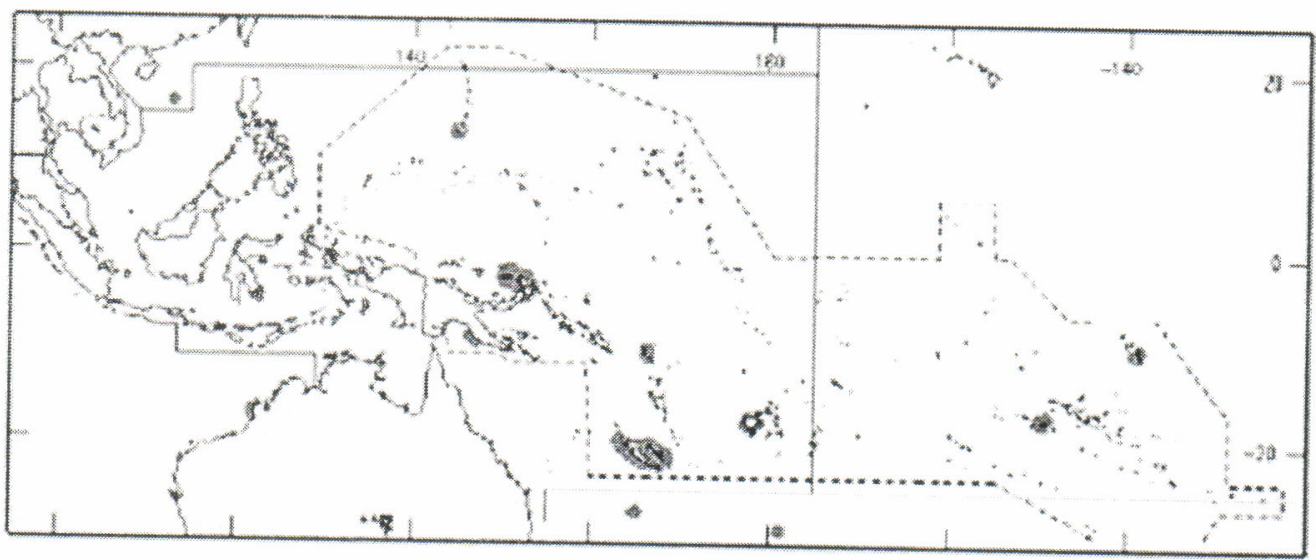

Figure 2. Geographic distribution of Epinephelus octofasciatus Griffin (1926) at western Central Pacific (Randall, 2001 in Carpenter \& Niem, 2001).

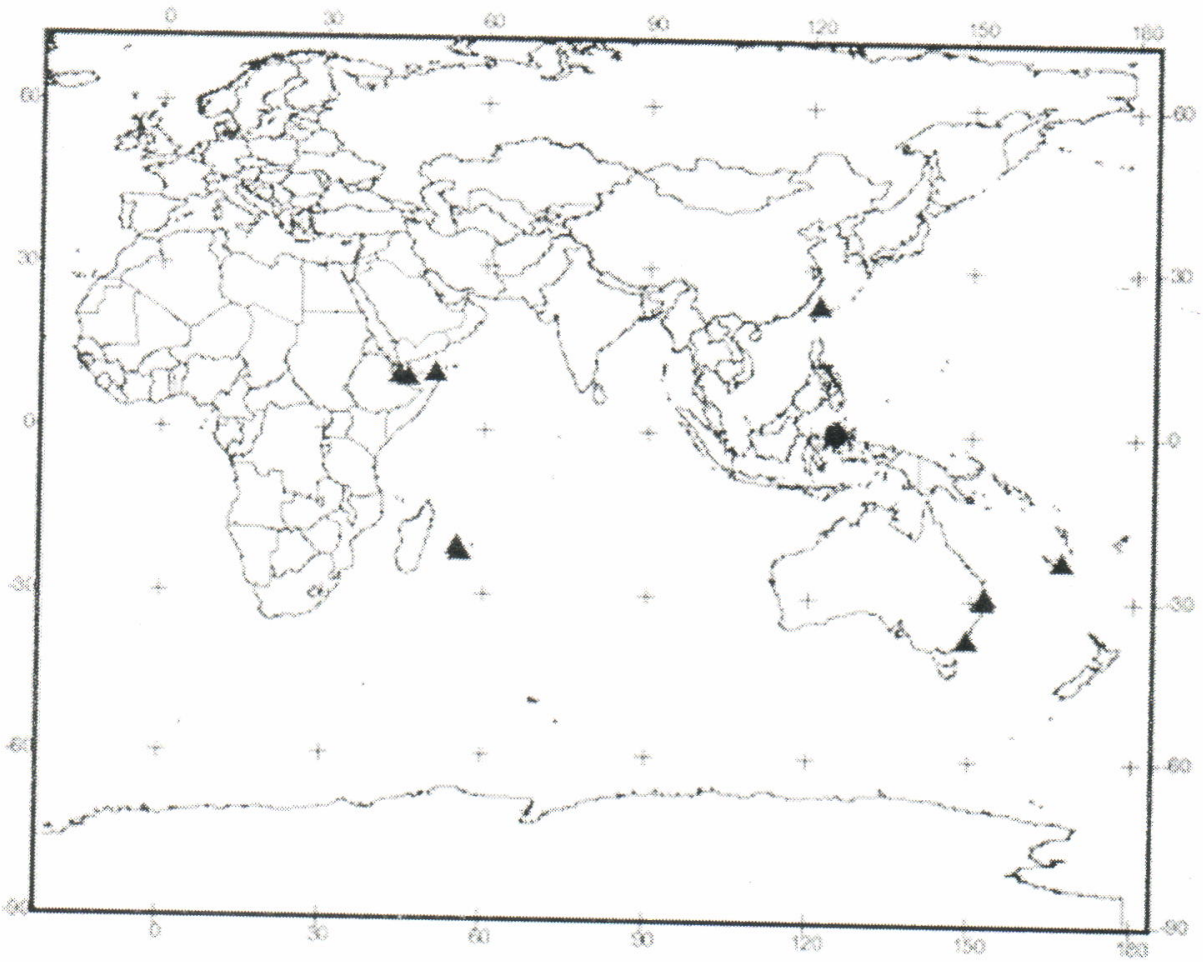

Figure 3. Geographic distribution of Epinephelus octofasciatus Griffin (1926) in the world represented by triangle (position were downloaded from Froese \& Pauly (eds.), 2006.) and specimen collected from Bitung, Indonesia represented by circle. 